\title{
El espacio de las redacciones: novelando en el periódico y reporteando en la novela de America Latina
}

\author{
The Newsroom Space: 'Noveling' in Newspapers and Reporting in Novels in \\ Latin America
}

\author{
Néfer Muñoz Solano \\ Modern Languages Department \\ University of Dallas, Estados Unidos
}

\section{Resumen}

Este artículo investiga las imbricaciones y porosidades entre la ficción y la no ficción en América Latina, y analiza un proceso textual de doble vía en el que escritores que trabajaron en periódicos incluyeron estilos y características de la literatura en su quehacer periodístico al mismo tiempo que crearon obras de ficción basadas o influenciadas en su labor como reporteros. Este dialogismo discursivo, articulado en un espacio que aquí se denomina la "sala de narración», es un fenómeno con profundas raíces en la tradición literaria latinoamericana y ha producido textos con diferentes grados de hibridez que relativizan el argumento de quienes consideran que hay fronteras definitivas entre los discursos literarios y periodísticos de América Latina.

Palabras clave: literatura latinoamericana, ficción, no ficción, novela, periódico, salas de redacción

\section{Abstract}

This article investigates the imbrications and porosities between fiction and nonfiction in Latin America. It analyzes a two-way textual process in which writers working for newspapers included styles and characteristics of literature in their journalistic texts as they simultaneously created works of fiction that were based on or influenced by their journalism. This discursive dialogism occurs in a space herein called the "narrative room". Deeply rooted in Latin American literary tradition, this phenomenon has produced texts 
with different degrees of hybridity that blur the boundaries between Latin American literature and journalism.

Keywords: Latin American literature, fiction, non-fiction, novel, newspaper, newsroom

\section{Introducción}

$\mathrm{E}$ $\mathrm{n}$ el año 1886 , el poeta nicaragüense Rubén Darío, en uno de sus múltiples viajes, arriba a Santiago de Chile y lo primero que hace al llegar a la capital chilena es comenzar a trabajar en un periódico. En aquellos momentos, las salas de redacción en América Latina eran epicentros de efervescencia intelectual y Darío lo describe así en su autobiografía:

[...] entré inmediatamente en la redacción de La Época, que dirigía el señor Eduardo Mac-Clure, y desde ese momento me incorporé a la joven intelectualidad de Santiago. Se puede decir que la élite juvenil santiaguina se reunía en aquella redacción, por donde pasaban graves y directivos personajes. Allí conocí a Don Pedro Monti; a Don Agustín Edwards, cuñado del director del diario; a don Augusto Orrego Luco; al doctor Federico Puga Borne, actual ministro de Chile en Francia, y a tantos otros que pertenecían a la alta política de entonces (Darío, 1991, p. 35).

Para Darío, la sala de redacción funciona metafóricamente como un «puerto» de llegada. Después de todo, este escritor es un viajero; está lejos de su país natal. Así que la sala de redacción le ayuda a entrar en contacto de una manera directa y eficaz con los santiaguinos o, al menos, con el mundo "letrado» de Santiago. Las salas de redacción son también un "puerto» de salida que le permiten a Darío hacer conexiones cuando tiene que zarpar hacia otros países en su actividad escrituraria itinerante. Es decir, este espacio es un intenso punto de encuentro, de embarques y desembarques, de cargas y descargas, de importaciones, exportaciones e intercambios; es el escenario de un constante tránsito y una convergencia de personajes e ideas.

En la descripción de Darío, se nota la conjunción de dos grupos interrelacionados: la intelectualidad y la élite de la capital chilena. Como lo explica el crítico argentino Carlos Altamirano, el intelectual -como categoría- es parte de una minoría cultural y, en América Latina, por lo menos hasta mediados del siglo XX, esta figura era vista como una especie de "apóstol secular», un "educador del pueblo o de la nación» (2008, p. 15). De ahí que el periódico es una tribuna ideal para esta especie de misión o «apostolado» laico. El escritor peruano Manuel González Prada, al destacar el impacto de las opiniones vertidas en un periódico, llega incluso a escribir que, más que un sacerdote, el periodista ejerce «la dirección 
espiritual de las muchedumbres» (1924, p. 131). En la cita de Darío, el poeta nicaragüense hace una reiterada referencia a la juventud («joven», «juvenil») que parece entrar en contacto con gente más madura y establecida ("graves y directivos personajes»). Este pasaje señala una dinámica de relaciones tanto intra e intergeneracionales, así como intra e internacionales, es decir, una dinámica a la vez juvenil y cosmopolita, fundamental en la conceptualización y práctica de la modernidad, de la cual los periódicos son promotores fundamentales. ${ }^{1}$ De hecho, el crítico Aníbal González sostiene que es a través del periodismo que la modernidad se "textualiza» en América Latina y se difunde como ideología (1993, p. 19).

A continuación, en su autobiografía, Darío cuenta que una noche el director del diario chileno La Época informa a los periodistas de su sala de redacción que va a dedicar un número del periódico al poeta y filósofo español Ramón de Campoamor y, como incentivo, ofrece al grupo un premio de 200 pesos a quien escriba el mejor texto sobre el escritor. Darío cuenta que el premio lo ganó él con el siguiente poema:

Éste del cabello cano
como la piel del armiño,
juntó su candor de niño
con su experiencia de anciano.
Cuando se tiene en la mano
un libro de tal varón
abeja es cada expresión,
que volando del papel
deja en los labios la miel
y pica en el corazón (1991, p. 37).

Este poema destaca una relación dialéctica entre la juventud del autor homenajeado («candor de niño») y su madurez ("su experiencia de anciano») que, como síntesis, deja una obra poética. Además, presenta todo un circuito comunicativo del libro de papel al cuerpo humano («mano», «labios», «corazón»), que deleita y tal vez alimenta («miel»), mientras que estimula o provoca ("pica»). En otras palabras, hay una apelación a las sensaciones, puesto que la lectura (el sentido de la vista) estimula y nutre al cuerpo (los sentidos del tacto y el gusto). En este sentido, hay que recordar que del énfasis en las sensaciones deriva el sensacionalismo, una estética esencial en el surgimiento y consolidación del periodismo comercial moderno. ${ }^{2}$

Este poema de Darío es una décima -es decir, tiene diez versos y, cada uno de los versos, ocho sílabas-, por lo que llama la atención que haya escogido una métrica que, en el caso de América Latina, tradicionalmente ha estado asociada con la poesía popular rural. ${ }^{3}$ Acaso es una pose, desde la sala de redacción del periódico, un medio que populariza la lectura, para apelar a segmentos crecientes de lectores de clases medias urbanas, una estrategia en la que emplea una forma poética común del mundo rural para llamar la atención de los lectores urbanos. La sala de redacción del periódico parece ser entonces un espacio desde donde los intelectuales no solo escriben para otros intelectuales, con un lenguaje y un argot elitista, sino también donde escriben una especie de literatura popular para grandes audiencias.

Al justificar su triunfo, Darío explica que él gana el premio monetario porque, a diferencia de su décima, «ninguna de las poesías» escritas por los otros periodistas «resumía» la personalidad del poeta y filósofo español 
Campoamor (1991, p. 37). Inadvertidamente, lo que Darío está revelando es que quienes trabajan como periodistas en aquella redacción, además de escribir noticias, columnas y crónicas, también escriben versos, es decir, son escritores. En segundo lugar, al describir la clave para ganar el premio emplea el verbo «resumir», que por definición está ligado con dos características altamente valoradas por los periódicos modernos: la brevedad y la precisión. ${ }^{4}$ Este poema, al ser originalmente escrito para un periódico, tiene, en parte, un objetivo de homenaje informativo y, a la vez, con su métrica, su rima y sus imágenes sensoriales, va en la línea de una estética literaria que busca conmover y deleitar. Aquí se aprecia una imbricación conceptual y formal donde los discursos periodísticos y literarios se influyen, se tocan y se traslapan.

Esta historia de Darío, más allá de ser una anécdota biográfica llamativa, remite a una tendencia constante en la historia literaria de América Latina. De México hasta Argentina, entre la época colonial y el siglo XX, los periódicos impresos latinoamericanos llegaron a convertirse en uno de los principales barrios productivos de la Ciudad Letrada. El propio Darío publicó dos tercios de su obra en periódicos (Rotker, 1992, p. 15). Hay una multitud de casos a lo largo del continente que dan cuenta de este fenómeno: Roberto Arlt en Argentina, Lima Barreto y Carlos Drummond de Andrade en Brasil, José Marín Cañas en Costa Rica, Gabriel García Márquez en Colombia y Juan Carlos Onetti en Uruguay, solo para citar algunos nombres. Estos son ejemplos de escritores que trabajaron directamente como reporteros o editores en salas de redacción, porque, si se incluyera a todos los intelectuales latinoamericanos que frecuentaron o colaboraron de alguna manera con periódicos, habría que incorporar prácticamente a toda la República de las Letras.

Este trabajo es un acercamiento a distintos procesos de producción escrituraria originados en un espacio físico y simbólico, un lugar de intercambio social, económico y cultural donde muchos escritores latinoamericanos pasaron buena parte de sus años de formación o, en algunos casos, la mayoría de su carrera: las salas de redacción. Estos centros neurálgicos de periódicos, revistas y agencias de noticias eran, más que salas de redacción, lo que aquí se denomina "salas de narración». Las «salas de narración» son espacios críticos fundamentales en América Latina para la creación, el intercambio y la producción de conocimiento de la Ciudad Letrada. En esas salas confluyen espacios y tiempos disímiles: allí los periodistas-escritores trabajan en una relación dialéctica entre su individualidad autoral y la colectividad, de manera que lo individual pasa por el cedazo de lo colectivo, en una compleja relación con colegas, filtros editoriales y autoridades empresariales.

En las «salas de narración», los géneros escritos se «purifican» y se «separan», pero a la vez se "contaminan» y se «hibridan». Allí se escriben textos que son tachados y corregidos sucesivamente en una cadena especializada de trabajo. Estos textos o palimpsestos -donde la República de las Letras se informa, genera conocimiento, participa, debate, se edifica y, al mismo tiempo, se deleita- son representaciones (construcciones) del mundo y, en algunos casos, operan como una forma de 
literatura para las masas. En las «salas de narración", se originan diversos procesos de creación escrituraria, y este trabajo se centra en uno en especial, que tiene como característica una serie de flujos de doble vía: novelar en los periódicos y reportear en las novelas. En primer lugar, en estas «salas de narración», se producen textos informativos que serán publicados como noticias; no obstante, incluyen algunos rasgos -en su estilo, en su tono o en su imprecisiónque los hacen parecer piezas literarias, por ejemplo, la inclusión de situaciones exageradas o hiperbolizadas o la alusión a circunstancias y personajes que pudieran ser ficticios. En segundo lugar, y en una vía contraria, se aprecia la composición de poemas, obras de teatro, cuentos y novelas a partir de ideas que surgen dentro de la sala de redacción o que fueron noticias o informaciones reporteadas originalmente para el medio de comunicación impreso.

\section{Las salas de redacción como espacio narrativo}

La representación del espacio, como lo explica el crítico David Harvey, es trascendente porque afecta la forma en que las personas interpretan y actúan en el mundo (2012, p. 229). En este sentido, para entender la tradición literaria latinoamericana no solo es imprescindible estudiar "cómo» se escribe sino también desde «dónde» se escribe, ya que ese "dónde» puede tener una influencia determinante en los procesos del «cómo». Para efectos de este trabajo, al reflexionar sobre las representaciones literarias que se construyen desde el espacio de los periódicos, se usará el verbo «novelar» para aludir a la creación literaria en general, pero hay que apuntar que dentro o a partir de las "salas de narración" latinoamericanas se originaron no solo textos que han sido catalogados dentro del género de la novela sino también una vasta obra de poesía, ensayo, teatro y cuento, así como textos híbridos difíciles de categorizar.

En la historia literaria latinoamericana, las «salas de narración» son espacios de mimetismo mutuo entre los discursos periodísticos y literarios, entre la ficción y la no ficción. Es importante resaltar que las "salas de narración» son espacios físicos y simbólicos muy diferentes a otros espacios escriturarios apartados y solitarios donde no hay interrupciones -como una biblioteca, una oficina privada o el despacho de una casa, por ejemplo-. Al contrario, las "salas de narración" son más bien ambientes donde es común que haya conversaciones en voz alta, ruidos, movimientos, interrupciones y distracciones que pueden «contaminar», modificar e influenciar el estilo, el tono y el contenido de los textos. Además, es imperativo hacer notar que no hay una «sala de narración» arquetípica ni única, sino que hay muchas, que varían en dimensiones, recursos, tecnologías y prácticas, de acuerdo con países específicos y diferentes épocas; sin embargo, estos recintos comparten algunas características y problemáticas para el literato que se tratarán en este trabajo.

En esta dinámica de creación dentro de este espacio, no hay pocas fricciones o contradicciones, no solamente entre diferentes actores participantes en aquellos espacios sino también al interior mismo de la figura principal que aquí interesa: el escritor que trabaja como periodista, 
es decir, el "periodista-escritor» o el «escritor-periodista»; por ejemplo, cuando esta figura enfrenta los dilemas de la relación entre trabajo asalariado y creación artística, entre capitalismo y arte o entre identidad autoral y autoridad empresarial.

Sobre estas tensiones al interior de la República de las Letras, el escritor cubano Julián del Casal criticaba que «lo primero que se hace al periodista, al ocupar su puesto en la sala de redacción, es despojarlo de la cualidad indispensable al escritor: de su propia personalidad» (1963, p. 287). El peruano Manuel González Prada se quejaba de que la escritura en periódicos difundía "una literatura de clichés» (1924, p. 133) y el mexicano Manuel Gutiérrez Nájera añadía que el estilo periodístico era «brutal» pues no tenía ni «literatura, ni gramática, ni ortografía» (Rotker, 1992, p. 74). El brasileño Olavo Bilac protestaba al alegar que su arduo trabajo como escritor dentro de un periódico se deshacía y desaparecía más fácilmente que las pisadas de un caminante sobre la nieve (Costa, 2005, p. 51). Sin embargo, el uruguayo José Enrique Rodó reconocía que los escritores que trabajaban en las redacciones de periódicos adquirían allí una agilidad en su escritura y era una manera de entrenar su «claridad y precisión» (1967, p. 54). Visto de esa manera, cuando los intelectuales latinoamericanos debaten sobre su papel en los periódicos, hay una constante estela de preocupaciones, lamentos y disyuntivas, pero a la vez de aceptaciones y reconocimientos. Las "salas de narración» son, entonces, espacios dialógicos y dialécticos.

El filósofo Henri Lefebvre ha escrito que un espacio social es un producto social (1991, p. 26). Los seres humanos crean los espacios en los que viven y estos son conformados por intereses de clase y por toda una serie de fuerzas en tensión. De ahí que el espacio no sea simplemente algo que se herede de la naturaleza o del pasado, sino que es producido y reproducido por intenciones humanas específicas. Porque, además de producir bienes y servicios, las economías producen espacios. Lefebvre está en contra de entender al espacio como un continente, como un lugar que simplemente "contiene» actividades. Más bien, las paredes, los caminos y, en general, el diseño de un espacio determinado, privilegian cierto tipo de actividades e inhiben otras; empoderan los proyectos de cierto tipo de actores y desincentivan los de otros. El espacio, en esta concepción, no es un mero medio o una lista de ingredientes sino la interrelación de formas geográficas, ambientes construidos, sentidos simbólicos y rutinas de vida. El espacio es un elemento activo que toma parte en el diseño de las relaciones sociales.

El escritor cubano José Martí materializó en un verso de sus Versos libres la que probablemente es una de las mejores ilustraciones del dialogismo y la dialéctica que vive en carne propia el escritor-periodista: "Ganado el pan, hágase el verso» (1939, p. 16). Para Martí, el periodista-escritor, es decir, él mismo, trabaja en un periódico para generarse un ingreso económico, pero, «a partir de», «durante» o «después de» ese trabajo ejercido durante el día como periodista, se generan las ideas para sus creaciones literarias. Primero, hay que ganarse el pan; después, se debe crear el verso: es el utilitarismo en tensión directa con el arte. No es casualidad que más de la mitad de la obra de Martí sean textos publicados 
en periódicos (Rotker, 1992, p. 15). Este fenómeno, vivido con particularidades disímiles, por diferentes creadores en «salas de narración» muy variadas, es compartido, sin embargo, en las distintas latitudes latinoamericanas como una constante, principalmente, en los siglos XIX y XX. El resultado es una serie de textos con distintos grados de hibridez que relativizan el argumento de quienes, conceptualmente, establecen fronteras definitivas entre la literatura y el periodismo en América Latina. Las «salas de narración» son, entonces, espacios físicos y simbólicos de flujos, afirmación, construcción y creatividad, pero también de zigzagueos, porosidades, intercambios y contornos inestables.

\section{João do Rio, un flâneur con salario}

El crítico Tulio Halperín Donghi explica que en América Latina el intelectual moderno tiene como antecedente al letrado colonial, quien detentaba la representación de la "cultura savant», y quien, con el transcurrir del tiempo, pasó por una serie de transiciones, dislocamientos y metamorfosis (citado por Altamirano y Myers, p. 20). El siglo XIX es una época de fragmentación y modernización desigual en América Latina, la cual conllevó la privatización de la escritura (Ramos, 1989, p. 8). La figura del escritor, quien en un momento dado había estado a cargo de la formación de la ley y de los nuevos estados nacionales, fue desplazada del mando de la administración estatal y tuvo que buscar otros espacios para marcar su autoridad intelectual. Pedro Henríquez Ureña explica que lo que hubo fue una división del trabajo y los intelectuales se separaron de la política (Rotker, 1992, p. 57). Es entonces cuando los escritores comenzaron a realizar tareas como dedicarse a la educación, vender obras a compañías teatrales, escribir folletines, hacer traducciones, vender artículos a diarios o, en muchos casos, convertirse en periodistas de planta, un trabajo que respondía al nombre de «reporter» (Rama, 1984, p. 63).

Uno de los «reporters» más emblemáticos de América Latina de comienzos del siglo XX es el brasileño João do Rio, un periodista que pasó a formar parte del canon de la literatura de Brasil con una prolífica obra compuesta principalmente por crónicas y relatos sobre la ciudad de Río de Janeiro. Entre 1899 y 1921 João do Rio «publicó para» y «trabajó en» diversos diarios, en los cuales escribió sobre temas como las religiones, los vicios, las costumbres, los personajes, la música, el fútbol y la intensa vida bohemia de Río de Janeiro. En su proceso escriturario como cronista, este escritor documentó su época y articuló lo que el crítico Aníbal González denomina una «arqueología del presente» (1983, p. 74). La obra de João do Rio, que oscila entre la ficción y la no ficción, lo legitimó en vida como una figura icónica de la Ciudad Letrada y lo llevó a ganar una plaza como miembro de la Academia Brasileña de las Letras.

Su nombre de pila era Paulo Barreto, pero al convertirse en periodista y escritor comenzó a firmar como «João do Rio», que en español significa «Juan de Río». La elección de este pseudónimo no es una casualidad ya que «João» es un nombre muy frecuente en portugués y evoca lo común, mientras que el apellido «do Rio» alude a un dominio de lo urbano, a una pertenencia y a una 
centralidad. Su pseudónimo da a entender que él (como periodista y escritor) es un personaje común que transita, observa y articula la ciudad, a la cual pertenece, desde su escritura. $\mathrm{Al}$ asumir su «nombre de pluma», João do Rio decide que él mismo es una metonimia, una figura contigua y, a la vez, inseparable -literalmente- de la urbe.

En un texto suyo del año 1911, João do Rio describió así el espacio físico de una sala de redacción:

La sala estaba llena. Las secretarias especiales ocupadas todas, la gran mesa del centro repleta de reporters, con la cabeza baja, escribiendo, llenando las tiras de papel. En las ventanas los periodistas hablaban. En la mesa del secretario, dos sujetos pedían alegatos. Las preguntas, las risas, las carcajadas se cruzaban.

De instante en instante, el resonar del teléfono llamaba a la administración, a las delegaciones distantes, a la tipografía. El redactor principal dejaba su oficina, con una sonrisa en sus labios. Era admirado y tratado con deferencias especiales. El carro lo esperaba, un carro muy bien puesto. Un literato en plena apoteosis de su aclamada crónica contaba paradojas entre un grupo, con aires íntimos y superiores... (2009, p. 182)

Esta cita es un retrato de un concurrido espacio que está poblado por cruces, tanto de personajes («secretarias», "reporters», jefes y visitantes) como de flujos (ruidos, conversaciones, «preguntas», "carcajadas»). En este pasaje presenciamos cómo, a partir del espacio, se distribuye el poder social en la vida cotidiana de los personajes. Lefebvre explica cómo el dominio sobre el espacio constituye una fuente fundamental del poder social (2012, p. 251). En el texto de João do Rio la dinámica capitalista del periódico, con su división especializada del trabajo, es lo que predetermina las diferentes capas o estratos socioeconómicos así como el ejercicio del poder. Si bien los «reporters» están en el centro, su espacio es compartido y escriben con la cabeza baja; su poder (central) es una fachada, un poder apenas relativo y superficial. El «redactor principal», por su parte, está en un espacio apartado pero individual; de manera que, si bien no está en el centro aparente, sí está en la cima de la jerarquía y eso le permite ejercer el poder, algo que lo hace objeto de halagos y deferencias. Además, se muestra a la figura del «literato» que trabaja como cronista, a quien rodean y de quien escuchan sus relatos orales.

Este texto de João do Rio muestra cómo la escritura es el motor del espacio colectivo. Los «reporters» escriben dialógicamente, en medio de traslapes e intermitencias, entre la algarabía y el resonar de los teléfonos, en un ambiente que remite al de una colmena. En este entorno hay dos elementos que resaltan y se imbrican: la pregunta y la risa, que son precisamente dos componentes significativos del periódico moderno. Preguntar en el espacio de la "sala de narración» no solamente es un pre-requisito de la escritura sino también un propósito: dar la sensación al público lector de que ellos también -aunque sea de una forma vicaria, a través de las noticias que leen- están cuestionando, interrogando, pensando y analizando. Por otro lado, la risa es 
el resultado del entretenimiento, pero también un mecanismo que permite el desahogo y la burla, así como la crítica. En este fragmento, los periodistas parecieran entretenerse y reírse con desenfado ante las informaciones de lo que pasa en el interior y el exterior de la sala. Como notaba el filósofo Henri Bergson, hay una asociación directa entre la risa y el absurdo (1911, p. 112), y qué mejor lugar para atestiguar los absurdos humanos y reírse de ellos que en el espacio de un periódico, que funciona como archivo de la vida diaria de la modernidad.

El crítico brasileño Renato Cordeiro Gomes considera que João do Rio es la definición de "periodista moderno»: un escritor con una pasión especial por salir a recorrer las calles, en las cuales buscaba las fuentes para sus textos (1996, p. 34). De manera que João do Rio es un ejemplo del zigzagueo constante entre el interior de las «salas de narración» y el exterior del espacio urbano. Esa «pasión» por salir a las calles remite a una figura literaria muy conocida del siglo XIX, el flâneur. El poeta francés Charles Baudelaire describió al flâneur como un personaje de la modernidad, una figura que coincidía con la de muchos artistas, poetas y novelistas, quienes salían a pasear sin destino fijo por las calles de París para observar la estética y los acontecimientos urbanos, zambulléndose de manera anónima en la multitud, en medio de lo fugitivo y lo infinito (1986, p. 9). Más tarde, el crítico alemán Walter Benjamin describió al flâneur no solamente como un espectador sino también una especie de detective que investiga a la ciudad (1997, p. 40). De manera que la urbe es entonces un objeto de observación, pero también un intenso espacio de acción y descubrimientos. En ambas reflexiones, tanto para Baudelaire como para Benjamin, el espacio físico del flâneur es uno abierto y al aire libre, un paisaje exterior donde dominan las vitrinas, las calles, las fachadas y el asfalto, un espacio donde se escribe sobre el presente y se captura la eternidad del momento.

La crítica Viviane Mahieux, al estudiar la figura de escritores latinoamericanos que han trabajado en periódicos, observa cómo el periodista es una nueva versión del flâneur, pero, en este caso, un flâneur con salario (2011, p. 42). La pertinente observación de Mahieux parece comprobarse en el hecho de que mientras el flâneur permanece en la calle y vaga por los vericuetos urbanos sin restricciones temporales por un puro placer estético, el periodista tiene que regresar a la redacción, presionado por una hora de cierre. A diferencia del flâneur descrito por Baudelaire y Benjamin, el trabajo del periodista no es solitario, sino que más bien es parte de un plan colectivo de producción escrituraria, ya que en la "sala de narración» los textos son influenciados por comentarios, sugerencias, correcciones, adiciones e inclusive censuras de otros colegas, editores y autoridades del diario. Es así como el periodista opera en un espacio que se desdobla como una bisagra: en primer lugar, en el exterior de la urbe, donde observa, interactúa y recaba información y, en segundo lugar, en el interior de la "sala de narración», donde escribe en un entorno comunal e interactivo. El periodista es entonces una figura cultural que documenta los flujos y la historia presente de la ciudad; es el amanuense de la actualidad que, para usar la descripción de Baudelaire, es siempre fugitiva. 
La descripción de la sala de redacción de João do Rio es parte de un texto titulado «Esplendor y miseria del periodismo», tras cuya lectura no se puede tener certeza si es una crónica, un cuento, o una crónica ficcionalizada, puesto que esta pieza sigue un patrón de hibridez muy presente en la obra de este autor y común entre muchos "periodistas escritores» latinoamericanos. El texto cuenta la historia de un joven del noreste de Brasil, quien en busca de mejores oportunidades, migra a la urbe de Río de Janeiro. El muchacho llega fortuitamente a una sala de redacción y atestigua cómo los periodistas, sin necesariamente tener talento, pueden llegar a conseguir gloria, fama y dinero. Es entonces cuando el joven inmigrante resuelve que él mismo quiere convertirse en periodista. El protagonista del relato entonces intenta ser contratado dentro de la sala de redacción y, cuando finalmente lo logra, se percata de cómo aquello, que en principio le había parecido esplendoroso, no era más que una apariencia, una ilusión: tenía que trabajar arduamente sin horario, usualmente sin tiempo para comer, y todo a cambio de un sueldo irrisorio. En su puesto como reportero observa la corrupción reinante entre los diarios y el poder político, así como entre los periodistas y los intereses políticos y privados, en un ambiente donde son comunes los sobornos. Es decir, descubre cómo la letra impresa -como verdad-es traficada como materialidad al mejor postor.

En este relato de João do Rio, el joven protagonista comienza a vender su escritura a diferentes fuentes, esperando a cambio beneficios personales. Sin embargo, su trabajo no es retribuido como lo esperaba, ya que sus contrapartes no siempre cumplen con lo prometido. Es entonces cuando llega a la conclusión de que el trabajo en las salas de redacción es «una miseria infernal» porque "no era un hombre» sino más bien «era un futuro número líneas no pagas» (do Rio, 2009, p. 185). Esta es una anagnórisis aristoteliana, una revelación, en la que el personaje descubre la farsa, la trampa escrita por su propia letra. Conforme avanza la historia, el personaje -de quien nunca se dice su nombre- está cada vez está más endeudado y, debido a su ocupada agenda, deja de leer libros y confiesa haberse convertido en «una especie de ignorancia enciclopédica, al servicio de un número de gente, que se servía de él para trepar, para subir, para ganar, con cariño y cinismo» (Do Rio, 2009, p. 186).

La fortuna del joven periodista cambia de rumbo cuando en la sala de redacción le asignan el trabajo de telegrafista. Es a partir de entonces cuando comienza a vender clandestinamente, a un precio considerable, información a autoridades de fuera de la capital y ese es el primer paso de su ascenso. Eventualmente, el periodista nordestino se consolida como una figura poderosa, con un solvente ingreso que le permite frecuentar restaurantes caros y gozar de la amistad de personajes de influencia. El relato termina cuando un día aparece en la redacción otro joven inmigrante nordestino: un nuevo muchacho que dice que aspira a ser periodista. El protagonista original de la historia trata de disuadir al nuevo inmigrante y le asegura que todo aquello es un espejismo, pero no logra cambiar el empeño del recién llegado. Entonces, el personaje principal, temiendo que en un futuro aquel muchacho pudiera convertirse en una figura 
poderosa -y en un eventual rival-, le expresa su decisión, con la cual cierra el texto: "Estou ás suas ordens para ajudal-o a collocar-se..." ("Estoy a sus órdenes para ayudarlo a colocarse...») (Do Rio, 2009, p. 190).

El crítico David Harvey explica que «el dinero puede utilizarse para gobernar el tiempo (nuestro tiempo y el de los otros) y el espacio. Recíprocamente, el dominio del tiempo y el espacio puede convertirse en dominio sobre el dinero» (2012, p. 251). Este texto de João do Rio es un retrato de un espacio físico y simbólico, pero al mismo tiempo es una fuerte crítica de ese sistema, del cual el propio João do Rio forma parte, donde el dinero gobierna sobre el tiempo y el espacio. Es un texto que muestra el ambiente de "esplendor» y de "miseria» del "flâneur con salario», pero también de todos aquellos quienes de alguna manera escriben, trabajan, poseen o tienen relaciones con periódicos. Este texto aborda las complejas tensiones entre «arte» $\mathrm{y}$ «mercado», «verdad» y «mentira», «realidad»y «representación», así como el binomio de "superficialidad» versus "sustancia». El cierre del relato es un guiño alegórico sobre el tiempo efímero y cíclico de los diarios: cada día el periódico comienza de cero su proceso de producción y al final de la jornada hay un nuevo ejemplar, una nueva copia; al mismo tiempo, en una especie de mise en abyme, el protagonista comienza de cero su ascenso hasta convertirse en el periodista poderoso que había soñado y, al final, aparece un nuevo inmigrante nordestino que quiere replicar el proceso, para convertirse él mismo en el nuevo ejemplar, la nueva copia.

En este relato, João do Rio cuenta una historia cíclica -y al mismo tiempo cínica- a la vez que expone un juicio moral sobre un espacio y un tipo de escritura, al abrir un debate sobre las «verdades» que se narran en los periódicos, sobre cómo esas "verdades» son una construcción y también una transacción. Este escritor critica el ambiente del espacio de las "salas de narración» y los peligros para los escritores que se dedican al periodismo, ya que al trabajar para empresas periodísticas están, de una u otra forma, poniendo su «pluma de alquiler» (Costa, 2005, p. 11). De manera que João do Rio muestra cómo las «verdades» de los periódicos pueden ser, en realidad, falsedades disfrazadas, usadas por intereses individuales, gubernamentales o corporativos para manipular. El crítico Hayden White considera que, como artefactos verbales, tanto la escritura de la historia como la de una novela es indistinguible la una de la otra, ya que el objetivo de un historiador es el mismo que el de una novela: ambos quieren proveer una imagen verbal de la «realidad» (1985, p. 122). En su texto, João do Rio nos demuestra cómo los discursos periodísticos, como artefactos verbales, son también construcciones, y de cierta manera ficciones, ya que escribir sobre eventos del presente es también un proceso poético de creación.

\section{Conclusión: contactos de doble vía}

A fines del siglo XIX y comienzos del XX, se puede percibir cómo la configuración del espacio físico y simbólico de las «salas de narración» y las relaciones entre los escritores y el periodismo llama la atención de miembros de la República de las Letras, por ejemplo, del crítico y escritor uruguayo José Enrique Rodó: 
querámoslo o no, dentro de la modernidad, a todos nos toca vivir como periodistas ... Nuestros novelistas, nuestros dramaturgos, nuestros líricos, todos, con rarísima excepción, han sido alguna vez periodistas; y si les preguntáis qué recuerdos guardan del periodismo y lo que le deben, puede ser que os digan que la prensa diaria ha quitado algún tiempo o ha negado algún reposo a la vocación preferente de su espíritu; pero, en cambio os dirán también que en la práctica del periodismo adquirieron esa disciplina del trabajo, ese hábito de la producción ágil y asidua, y esa gimnasia de claridad y precisión, que desentumecen el estilo y adiestran las energías del entendimiento, como el aire libre y el pleno sol y la desenvuelta actividad de los músculos vigorizan el cuerpo entumecido en la quietud (1967, p. 54).

Cuando Rodó afirma, incluyéndose a sí mismo, con la primera persona del plural "a todos nos toca», se está refiriendo a los «intelectuales». De acuerdo con Zygmund Bauman, esta es una práctica endógena de auto-entendimiento (1987, p. 8). Es un intento por autodefinirse como intelectual latinoamericano, incluyendo en esta categoría a los escritores, los dramaturgos y los poetas, pero sin dar un abrazo completo a los periodistas, para quien no usa el posesivo «nuestros». De las palabras de Rodó se puede inferir la idea de que los intelectuales pueden trabajar como periodistas, pero no necesariamente todos los periodistas son intelectuales.

En este ejercicio de autodefinición, Rodó otorga al periodismo una connotación de fardo irremediable («querámoslo o no») con el que se carga a pesar de que no se quiera. Esta es una queja común entre muchos escritores latinoamericanos que trabajan como periodistas durante los siglos XIX y XX. La dinámica del trabajo periodístico es criticada por los intelectuales, tanto desde el exterior como en el interior de las "salas de narración". El carácter telegráfico y la rapidez con que tienen que ser elaborados los productos escriturarios suponen una falta de reflexión y, además, debido a la urgencia intrínseca de la escritura periodística, la posibilidad de contenidos poco pulidos y la eventual proliferación de errores gramaticales y conceptuales.

Es así, como en el contexto de la modernidad, el "periodista escritor» (lo quiera o no) tiene que depender de una relación comercial de intercambio para generar un ingreso económico. Esta situación es vista como una interrupción de la creación literaria. El propio Rodó admite que el periodismo le quita tiempo y le niega «reposo» a su vocación de escritor; pero, por otra parte, reconoce que trabajar para la prensa le brinda tanto un «hábito de producción ágil y asidua» como una "gimnasia de claridad y precisión» que «desentumecen el estilo» (1967, p. 54). Así Rodó recurre a una metáfora de movimiento para describir la condición doble del «periodista escritor», en una relación dialéctica entre la quietud y la circulación que deja como síntesis una serie de textos escritos en un zigzagueo entre la reflexión intelectual y la premura por la hora del cierre.

El crítico y escritor Tomás Eloy Martínez, uno de los periodistas argentinos más reconocidos del siglo XX, en un análisis sobre las nebulosas fronteras entre la ficción y la no ficción en América Latina se pregunta dónde está 
la línea divisoria entre lo que es periodismo y lo que es historia, "qué es qué» (2004, p. 40). Su reflexión se origina a partir de su propia producción y de las fronteras nebulosas entre periodismo y literatura. En la década de 1970, Martínez había publicado en Buenos Aires unas memorias del caudillo y expresidente Juan Domingo Perón que fueron reproducidas por más de cincuenta periódicos latinoamericanos. Aquellas memorias eran el resultado de una serie de entrevistas que durante cuatro años Martínez realizó al líder político, en las que Perón omitió contar algunos detalles importantes de su vida personal. Sin embargo, a pesar de que Martínez le solicitó expresamente aclarar esos pasajes, el político decidió publicar las memorias con aquellas elipsis.

Años más tarde, Martínez decidió retomar aquel trabajo, originalmente pensado y publicado como texto periodístico, y lo convirtió en materia prima para novelar. El resultado fue un producto completamente nuevo, en el que hibridó datos históricos con anécdotas ficticias, $\mathrm{y}$ al que le dio el sugestivo y oximorónico título de $L a$ novela de Perón; oximorónico porque la palabra "novela» evoca un universo ficcional y el apellido «Perón» remite a un período histórico específico, de hechos y circunstancias políticas muy concretas. En una de las escenas de la novela, la entonces actriz Eva Duarte -más tarde conocida como Evita- se encuentra por primera vez con Perón en un festival benéfico y en un momento de su conversación ella se acerca y le susurra al oído: «Coronel, gracias por existir». Para darle verosimilitud a este episodio, el narrador justificó que aquella frase la había descubierto fortuitamente al hacer un trabajo periodístico.
Según detallaba, al hurgar en los archivos nacionales de Washington D.C., se había encontrado con un video documental y, tras analizar cuidadosamente las imágenes, había logrado leer esas palabras de los labios de Evita (Martínez, 2004, p. 48).

Tiempo después, Tomás Eloy Martínez se percató de que esa frase de su novela, que era de su entera invención, iba a ser usada en Argentina en el museo del peronismo. Para aclarar el equívoco, decidió entonces escribir un artículo en uno de los diarios de mayor circulación de Buenos Aires donde aclaraba que la frase era ficticia. Aquella explicación generó una sorpresiva reacción:

Dos sindicatos publicaron al día siguiente avisos publicitarios furibundos acusándome de mancillar la memoria de la «compañera Evita» por negar lo que ella había dicho. Nunca pensé que «Gracias por existir» fuera una gran frase, pero por una razón u otra acertó en el blanco del mito: se convirtió en la frase que muchos devotos peronistas piensan que Evita debió decir. Ahora soy yo quien, cada vez que niega a Evita como autora de la frase, pareciera estar menoscabándola. El personaje Evita de mis novelas -el mito- se ha entrelazado con la Evita de la historia y la ha modificado (2004, p. 49).

En esta cita, Tomás Eloy Martínez está desovillando -o tratando de desovillar- los hilos de la maraña para comenzar a tejer una posible respuesta a su pregunta "¿qué es qué?». En otras palabras, intenta deslindar lo que es ficción de lo que no lo es; quiere 
determinar cuáles son las fronteras. Con este propósito, expone las zonas grises e intermedias de los traslapes. Por ejemplo, sostiene que ha descubierto un fenómeno al que llama "efecto de contigüidad»: textos que al ser publicados primero en periódicos o por su proximidad al discurso de los diarios pueden dar la impresión en el público lector de que son verdaderos cuando en realidad son ficcionales (2004, p. 41). Martínez explica, parafraseando a un crítico que analizó su novela, que un punto fundamental aquí no es distinguir qué es verdad sino qué podría ser verdad y qué es lo que cuenta como verdad para los lectores, porque «establecer la verdad en términos absolutos es una empresa casi imposible» (2004, p. 49).

Para Martínez, la única verdad posible es el relato de la verdad, la narración como verdad. Esto coincide con la posición del escritor peruano y ganador del Premio Nobel de literatura Mario Vargas Llosa -otro escritor que también ha ejercido el periodismo-, quien considera que la verdad de una novela depende «de su propia capacidad de persuasión» (1990, p. 10). Vargas Llosa argumenta que la verdad de una novela está en su habilidad mágica para comunicar una fantasía, de manera que "decir la verdad» para una novela es convencer al lector de la ilusión del argumento que está leyendo, mientras que «mentir» es ser incapaz de persuadir que aquel mundo de letras existe y es creíble: de ahí que toda buena novela dice la verdad y toda mala novela miente.

Si el periodista lidia -primordial, aunque no exclusivamente- con verdades factuales y, por otro lado, el escritor, en buena parte, con verdades ficcionales, ¿qué pasa entonces cuando tenemos una figura híbrida, al periodista escritor, que lidia con ambas $-y$ con todos sus matices intermedios- en su producción escrituraria, en muchos casos, de forma cotidiana? ¿Qué sucede, además, cuando el espacio físico donde conviven periodistas, escritores y la combinación de ambos es un espacio común? El resultado origina ejemplos tan diversos de hibridez escrituraria como las crónicas neoyorquinas de José Martí; los relatos de la guerra de Canudos escritos en Brasil por Euclides Da Cunha; las narraciones modernistas de Rubén Darío, Manuel Gutiérrez Nájera y Julián del Casal; los escritores de la revolución mexicana; los cables de la agencia Reuters redactados por Juan Carlos Onetti; las crónicas de Alejo Carpentier; los reportajes de César Vallejo; los aguafuertes de Roberto Arlt; los editoriales de Augusto Roa Bastos; las crónicas de Salvador Novo; y los textos de Elena Poniatowska, solo para citar algunos ejemplos.

Para Lefebvre, el espacio tiene un impacto directo en las relaciones sociales y, como hemos visto en este trabajo, también sobre las relaciones escriturarias y la escritura misma. De ahí que las «contaminaciones», los contactos, las influencias y las imbricaciones en el espacio de un periódico se vuelvan una posibilidad inevitable, no solamente entre los géneros que practica discursivamente una misma persona sino también entre las distintas figuras que pueblan y escriben en aquel espacio compartido. Por esto, ese lugar de interacción y narración, físico y simbólico, así como las relaciones que allí se articularon durante los siglos XIX y $\mathrm{XX}$, son fundamentales para entender los procesos de creación y recreación, 
presentación y representación de las realidades factuales y los universos ficcionales de América Latina.

\section{Notas}

1. Para el crítico Julio Ramos, la modernización es un proceso muy desigual en los distintos países de América Latina: «A diferencia de Europa, donde la modernización, ya en el siglo XIX, operaba con discursos racionalizados, independientes del orden general del saber decir, en América Latina las letras siguieron funcionando como el medio del proyecto modernizador hasta las últimas décadas del siglo. Esa desigualdad de la modernización, que seguía operando con discursos tradicionales, no orgánicos al capitalismo, caracteriza el campo intelectual anterior al 80 que a su vez buscaba autonomizarse de Europa y su hegemonía sobre la 'ciencia'. En ese mundo carente de discursos racionalizados, donde los intelectuales ya sospechaban los riesgos de la dependencia y la importación, las letras seguían sirviendo como modelo de la modernidad deseada» (Ramos, 1989, p. 45).

2. El sociólogo Michael Schudson explica cómo el sensacionalismo es crucial en el surgimiento de la prensa comercial en los Estados Unidos y el epicentro de este fenómeno estuvo en la ciudad de Nueva York durante la década de 1830. En esta metrópolis, donde florecieron el comercio, el transporte y las telecomunicaciones, surgen una serie de periódicos baratos dirigidos a las masas, conocidos como "penny papers», porque costaban un centavo o penique. La nueva prensa se distingue por su bajo precio y la publicación del género de noticias. Además, es distribuida en las calles por niños pregoneros, se financia con la venta de publicidad y alega una independencia de los partidos políticos. Este tipo de periodismo está directamente conectado con transformaciones sociales, económicas y políticas que Schudson llama «sociedad democrática de mercado» ("democratic market society»), impulsada por el surgimiento de la clase media urbana (1978, p. 30).

3. Las décimas son composiciones populares que se pueden declamar o cantar acompañadas con música. Sobre la importancia de las décimas, el escritor cubano Alejo Carpentier apunta: «Y el pueblo: ese pueblo latinoamericano, tan buen cantor de décimas, tan inventivo en su música, tan artista cuando se manifiesta su sentido plástico» (1967, p. 282).

4. Los textos periodísticos están escritos dentro de un contexto capitalista que toma como premisa que el público lector, debido a su trabajo, no tiene tiempo para lecturas prolongadas, por lo cual los textos deben ser breves y precisos. El crítico Lorenzo Gomis explica cómo el comienzo del primer párrafo de una noticia es «un resumen breve y ágil de los datos esenciales que constituyen el hecho» (2008, p. 84).

5. El crítico Carlos Altamirano define a los intelectuales como "personas, por lo general conectadas entre sí en instituciones, círculos, revistas, movimientos, que tienen su arena en el campo de la cultura. Como otras élites culturales, su ocupación distintiva es producir y transmitir mensajes relativos a lo verdadero (si se prefiere: a lo que ellos creen verdadero), se trate de los valores centrales de la sociedad o del significado de la historia, de la legitimidad o la injusticia del orden político, 
del mundo natural o de la realidad trascendente, del sentido o del absurdo de la existencia» (2008, p. 14).

6. La traducción al español es propia. El original en portugués dice: «A sala estava cheia. As secretarias especiaes todas ocupadas, a grande mesa do centro repleta de repórteres, de cabeça baixa, escrevendo, enchendo tiras. Às janelas jornalistas conversavam. À mesa do secretario, dois sujeitos pendiam súplices. As perguntas, os risos, as gargalhadas cruzavam-se. De instante a instante, o retinir do telephone ligava à administração, a delegacias distantes, à tipografia. O redactor principal deixava o seu gabinete, com o sorriso nos lábios. Estava admirável e era tratado com deferências especiaes. O carro esperava-o, um carro muito bem posto. Um literato em plena apotheose da chronica acclamada paradoxava num grupo, com, ares íntimos e superiores» (Do Rio, 2009, p. 182).

7. El título original en portugués es «Esplendor e miséria do jornalismo».

8. Hayden White explica: «Although historians and writers of fiction may be interested in different kinds of events, both the forms of their respective discourses and their aims in writing are often the same... the techniques or strategies that they use in the composition of their discourses can be shown to be substantially the same, however different they may appear on a purely surface, or dictional, level of their texts» (1985, p. 121).

\section{Bibliografía}

Altamirano, C., y Myers, J. (Eds.). (2008). Historia de los intelectuales en América Latina (Vol. 1-II). Katz.
Baudelaire, C. (1986). The Painter of Modern Life and Other Essays (J. Mayne, Trad.). Da Capo Press.

Bauman, Z. (1987). Legislators and Interpreters: On Modernity, PostModernity, and Intellectuals. Polity Press in association with B. Blackwell.

Benjamin, W. (1997). Charles Baudelaire: A Lyric Poet in the Era of High Capitalism. Verso.

Bergson, H. (1911). Laughter an Essay on the Meaning of the Comic. Macmillan.

Carpentier, A. (1967). Literatura y conciencia política en América Latina. En F. Fernández-Santos y J. Martínez (Eds.). Cuba, una revolución en marcha (pp. 277-284). Ediciones Ruedo Ibérico.

Casal, J. del. (1963). Crónicas habaneras. Dirección de Publicaciones, Universidad Cental de Las Villas.

Costa, C. (2005). Pena de aluguel: Escritores jornalistas no Brasil, 1904-2004. Companhia das Letras.

Darío, R. (1991). La vida de Rubén Darío escrita por él mismo. Biblioteca Ayacucho.

Do Rio, J. (2009). Esplendor e miséria do jornalismo. En E. Bouças \& F. Góes (Eds.), João do Rio: Melhores crônicas. Global Editora.

Gomes, R. C. (1996). João do Rio: Vielas do vício, ruas da graça. Relume Dumará.

Gomis, L. (2008). Teoría de los géneros periodísticos. Editorial UOC.

González, A. (1983). La crónica modernista hispanoamericana. J. Porrúa Turanzas.

González, A. (1993). Journalism and the Development of Spanish American Narrative. Cambridge University Press. 
González Prada, M. (1924). Horas de lucha. Tip. «Lux».

Harvey, D. (2012). La condición de la posmodernidad: Investigación sobre los orígenes del cambio cultural. Amorrortu.

Lefebvre, H. (1991). The Production of Space. Blackwell.

Mahieux, V. (2011). Urban Chroniclers in Modern Latin America: The Shared Intimacy of Everyday Life. University of Texas Press.

Martí, J. (1939). Versos libres. La Verónica, Imprenta de M. Altolaguirre.

Martínez, T. E. (2004). Ficción historia, periodismo: Límites y márgenes. Revista Digital Telar - Universidad de Tucumán, 37-54.

Rama, Á. (1984). La ciudad letrada. Ediciones del Norte.
Ramos, J. (1989). Desencuentros de la modernidad en América Latina: Literatura y política en el siglo XIX. Fondo de Cultura Económica.

Rodó, J. E. (1967). Obras completas (E. Rodríguez Monegal, Ed.; 2. ed.). Aguilar.

Rotker, S. (1992). La invención de la crónica. Ediciones Letra Buena.

Schudson, M. (1978). Discovering the News: A Social History of American Newspapers. Basic Books.

Vargas Llosa, M. (1990). La verdad de las mentiras: Ensayos sobre literatura. Seix Barral.

White, H. (1985). The Fictions of Factual Representation. En Tropics of Discourse: Essays in Cultural Criticism (pp. 121-134). Johns Hopkins University Press. 
